\title{
SISTEM INFORMASI LAPORAN PENCAPAIAN KOMPETENSI PESERTA DIDIK DI SMK NEGERI 1 PURWOKERTO
}

\author{
Irfan Santiko \\ STMIK AMIKOM Purwokerto \\ Jl Let. Jend. POL SUMARTO Watumas Purwonegoro \\ Purwokerto Jawa Tengah Indonesia 53113 \\ Email : sandtyco@gmail.com
}

\begin{abstract}
ABSTRAK
Teknologi informasi berperan penting dalam meningkatkan mutu dan kualitas pendidikan. Sistem informasi pencapaian kompetensi peserta didik adalah upaya dalam membantu sebuah lembaga pendidikan untuk memperoleh input siswa yang berkompeten. SMK Negeri 1 Purwokerto merupakan lembaga pendidikan yang bertugas menangani kegiatan-kegiatan yang berkaitan dengan pendidikan, dimana di sekolah tersebut memiliki sistem dalam mencari peserta didiknya. Salah satunya adalah sistem pembagian atau pengaksesan laporan pencapain peserta didik.Sistem yang dimiliki masih menggunakan cara - cara konvensional yang dinilai belum memadahi dan masih cukup terkendala. Oleh karena itu tujuan pada penelitian ini adalah membangun sebuah sistem untuk mendukung kinerja pemilihan beserta laporan pencapaian kompetensi peserta didik.

Melihat permasalahan yang ada, penulis mengambil metode untuk mengembangkan system penelitian adalah metode Sytem Development Life Cycle atau biasa disebut metode Waterfall. Adanya sistem ini dapat mempermudahkan para orangtua siswa untuk memantau nilai anaknya dan juga siswa atau wali peserta didik dapat mengakases laporan tersebut dengan cepat dan kapan saja tanpa kendala waktu dan jarak, dengan sistem ini pembagian laporan pencapaian kompetensi peserta didik menjadi 1 level lebih baik.
\end{abstract}

Kata kunci : Sistem, Kompetensi, Peserta Didik.

\section{PENDAHULUAN}

Perkembangan teknologi informasi dalam era globalisasi saat ini sangatlah tumbuh dengan sangat pesat. Perkembangan teknologi informasi saat ini member berbagai keuntungan dan kemudahan bagi manusia di abad ini. Berbagai aspek kehidupan dan kegiatan memerlukan adanya teknologi informasi untuk menunjang kebutuhan mereka masing-masing. Oleh karena itu teknologi informasi merupakan elemen yang sangat penting yang tidak bisa dipisahkan dengan peradaban dunia saat ini. 
Seiring perkembangan teknologi informasi yang sangat pesat tersebut, aspek yang tidak bisa terlepas dari hal tersebut ialah aspek pendidikan. Teknologi informasi berperan penting dalam meningkatkan mutu dan kualitas pendidikan di Indonesia. Hal ini internet yang merupakan bagian teknologi informasi memberi keuntungan dan kualitas terhadap dunia pendidikan.

SMK Negeri 1 Purwokerto merupakan lembaga pendidikan yang bertugas menangani kegiatan-kegiatan yang berkaitan dengan pendidikan, dimana di sekolah tersebut kurang memanfaatkan teknologi internet yang dapat mempermudah kegiatan sekolahnya. Salah satunya adalah sistem pembagian atau pengaksesan laporan pencapain peserta didik SMK Negeri 1 Purwokerto . Sistem pembagian laporan pencapaian peserta didik dilakukan secara manual dimana setiap wali kelas untuk pembagikan laporan pencapian kompetensi peserta didik dan wali peserta didik mendatangi sekolah tersebut untuk memperoleh hasil belajar anaknya selama 1 semester di SMK Negeri Purwoketo. Sistem ini dirasa kurang optimal dan efisien, wali peserta didik harus mendatangi sekolah tersebut setiap semesternya yang sangat membutuhkan banyak waktu bagi wali peserta didik yang tidak dapat menghadiri pembagian laporan pencapaian peserta didik SMK Negeti 1 Purwokerto dan laporan tersebut hanya bisa dilihat pada waktu tertentu.

Hal ini dapat memperlambat pencarian data nilai setiap peserta didik sewaktu data nilai tersebut diperlukan. Penulis melakukan beberapa penelitian terhadap sistem yang sedang berjalan dalam proses pembagian laporan peserta didik diperoleh hasil penelitian yaitu adanya masalah yang sedang dihadapi oleh sekolah tersebut yaitu dimana wali peserta didik tidak bisa hadir sehingga menimbulkan keterlambatan pengkasesan laporan pencapain kompetensi perserta didik bagi siswa yang ingin mengetahui hasilnya selama belajar 1 semester.

Adanya sistem ini dapat mempermudahkan para orangtua siswa untuk memantau nilai anaknya dan juga siswa atau wali peserta didik dapat mengakases laporan tersebut dengan cepat dan kapan saja tanpa kendala waktu dan jarak, dengan sistem ini pembagian laporan pencapaian kompetensi peserta didik menjadi 1 level lebih maju dibandingkan SMK yang masih manual. 


\section{TINJAUAN PUSTAKA}

Sistem (system) dapat didefinisikan pendekatan komponen. Dengan pendekatan komponen, sistem dapat didefinisikan sebagai kumpulan dari komponen yang saling berhubungan satu dengan yang lainnya membentuk satu kesatuan untuk mencapai tujuan tertentu. Contoh sistem yang didefinisikan dengan pendekatan ini misal sistem komputer yang didefinisikan sebagai kumpulan dari berbagai perangkat keras dan perangkat lunak (Jogiyanto, 2005).

Informasi merupakan data yang telah diproses sehingga mempunyai arti tertentu bagi penerimanya. Sumber dari informasi adalah Data, sedangkan Data itu sendiri adalah Kenyataan yang menggambarkanm suatu kejadian, sedangkan kejadian itu merupakan suatu peristiwa yang terjadi pada waktu tertentu dalam hal ini informasi dan data saling berkaitan (Jogiyanto, 2005). Definisi umum sistem informasi adalah sebuah sistem yang terdiri atas rangkaian subsistem informasi terhadap pengolahan data untuk menghasilkan informasi yang berguna dalam pengambilan keputusan (Jogiyanto, 2005).

Basis kata terdiri dari 2 baris yaitu Basis dan data. Basis kurang lebih dapat diartikan sebagai markas atau gudang, tempat terkumpul. Sedangkan data adalah representasi fakta dunia yang nyata mewakili suatu objek seperti manusia (pegawai, siswa, pembeli) barang, hewan dan sebagainya, yang diwujudkan dalam bentuk angaka huruf simbol bunyi atau kombinasi lainnya (Fathansyah, 2012).

DFD atau dalam bahasa Indonesia menjadi Diagram Alir Data adalah respresentasi grafik yang menggambarkan aliran informasi dan transformasi informasi yang diaplikasikan sebagai data mengalir dari masukan (input) dan keluaran (output)(Rosa, 2011).

Website merupakan kumpulan halaman-halaman yang digunakan untuk menampilkan informasi teks, gambar diam atau gerak, anmasi, suara, dan atau gabungan dari semuanya itu baik yang bersifat statis maupun dinamis yang membentuk satu rangkaian bangunan yang saling terkait dimana masing-masing dihubungkan dengan jaringan-jaringan halaman. Dimana satu halaman Web dengan halaman lainya disebut hyperlink, sedangkan teks yang dijadikan media penghubung disebut hyperteks (Hidayat, 2010). 


\section{METODE PENELITIAN}

Pengembangan sistem dapat didefinisikan sebagai penyusunan suatu sistem yang baru untuk menggantikan sistem yang lama secara keseluruhan atau memperbaiki sistem yang telah ada. Metode pengembangan sistem yang banyak digunakan salah satunya adalah metode SDLC atau yang sering disebut juga System Development Life Cycle adalah proses mengembangkan atau mengubah suatu sistem perangkat lunak dengan menggunakan model-model dan metodologi yang digunakan orang untuk mengembangkan sistem-sistem perangkat lunak sebelumnya (berdasarkan best practice atau cara-cara yang sudah teruji baik).

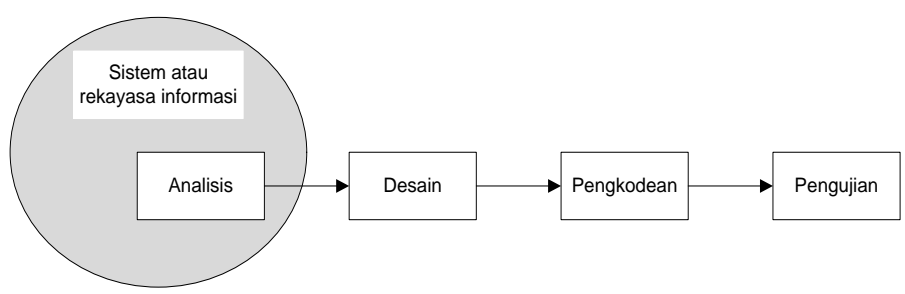

Gambar 1 Model Waterfall ((Rosa, 2011))

Dalam metode pengembangan system ini, penulis menggunakan metode SDLC (System Development Life Cycle) dengan model air terjun (waterfall) sering juga disebut model sekuensial linear (sequential linear) atau alur hidup klasik (classic lifecycle). Model air terjun menyediakan pendekatan alur hidup perangkat lunak secara sekuensial atau terurut dimulai dari analisis, desain, pengodean, pengujian dan tahap pendukung (support) atau pemeliharaan (maintance). Model ini adalah model yang banyak digunakan. Model air terjun (Rosa, 2011) dapat dilihat pada gambar 3.1 Model Waterfall.

1. Analisis

Proses pengumpulan kebutuhan dilakukan secara intensif untuk mespesifikasikan kebutuhan perangkat lunak agar dapat dipahami perangkat lunak seperti apa yang dibutuhkan oleh user. Spesifikasi kebutuhan perangkat lunak pada tahap ini perlu untuk didokumentesikan.

2. Desain

Desain perangkat lunak adalah proses multi langkah yang fokus pada desain pembuatan program perangkat lunak termasuk struktur data, arsitektur perangkat 
lunak, representasi antar muka, dan prosedur pengodean. Tahap ini mentranslasi kebutuhan perangkat lunak dari tahapan analisis kebutuhan kerepresentasi desain agar dapat diimplementasikan menjadi program pada tahap selanjutnya (Rosa, 2011).

\section{Pengodean}

Desain harus ditranslasikan kedalam program perangkat lunak. Hasil dari tahap ini adalah program komputer sesuai dengan desain yang telah dibuat pada tahap desain .

\section{Implementasi}

Sistem telah dianalisis dan diselesaikan secara rinci dan teknologi telah diseleksi dan dipilih. Tiba saatnya kita untuk diimplementasikan (diterapkan). Tahap implementasi sistem (systems implementation) merupakan tahap meletakan sistem untuk siap dioperasikan.

5. Pengujian

Pengujian fokus pada perangkat lunak secara dari segi lojik dan fungsional dan memastikan bahwa semua bagian sudah diuji. Hal ini dilakukan untuk meminimalisir kesalahan (error) dan memastikan keluaran yang dihasilkan sesuai yang diinginkan (Rosa, 2011). Dalam penelitian ini pengujian sistem akan menggunakan pengujian Black-Box.

6. Perawatan (maintanence)

Perawatan termasuk pembetulan kesalahan yang tidak ditemukan pada langkah sebelumnya. Perbaikan implementasi unit sistem dan peningkatan jasa sistem sebagai kebutuhan baru ditemukan. Kegiatan yang yang dilakukan dalam perawatan yaitu dengan mengecek beberapa sistem operasi apakah bekerja sebagaimana fungsinya, sehingga fungsi dari aplikasi yang digunakan benar-benar dalam kondisi yang baik sehingga dalam proses operasi dapat terlaksana sesuai dengan fungsinya. 


\section{HASIL DAN PEMBAHASAN}

\section{Analisis Sistem yang berjalan}

Proses pengaksesan laporan pencapaian kompetensi peserta didik pada sistem yang sedang berjalan dilakukan dengan cara manual dimana wali siswa datang ke sekolah untuk melihat laporan pencapaian kompetensi peserta didik pada akhir masa pembelajaran. Sistem ini dirasa kurang efektif dikarenakan sistem ini mengharuskan wali peserta didik datang ke sekolah untuk mengambil laporan pencapaian kompetensi peserta anaknya, padahal tidak semua wali siswa dapat mengunjungi sekolah saat pembagian laporan pencapaian kompetensi peserta didik dikarenakan alasan tertentu, dan nilai raport hanya dapat diakses di waktu tertentu saja.Berikut ini alur pengkasesan laporan nilai raport.

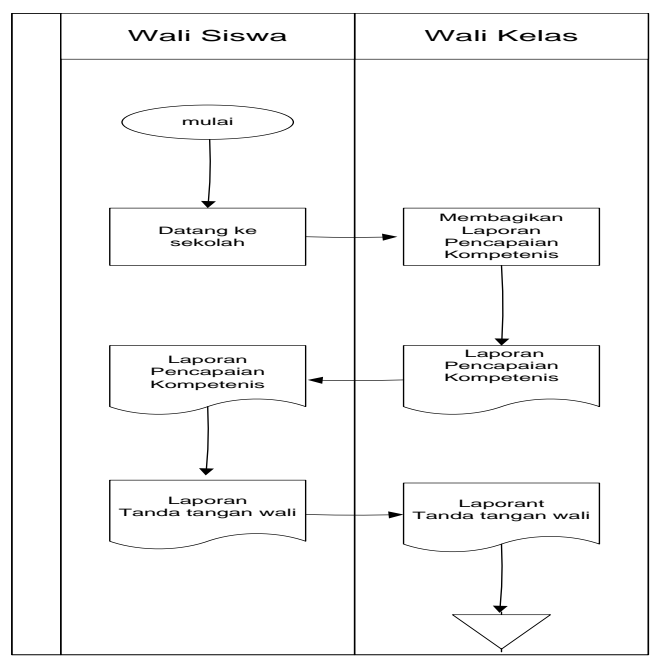

Gambar 1 Flowchart pengaksesan laporan nilai raport

\section{Identifikasi Masalah}

Dengan berkembangnya dunia pendidikan proses pengaksesan laporan pencapaian kompetensi peserta didik pada sistem yang sedang berjalan masih belum dapat mengatasi beberapa permasalahan maka diperlukan suatu sistem ini yang dapat menawarkan kemudahan memperoleh informasi dimana saja dan kapan saja, terutama dalam hal representasi informasi perkembangan kemampuan peserta didik dengan proses manajemen database yang praktis 
tentang pengaksesan laporan pencapaian kompetensi yang dibutuhkan peserta didik dan wali peserta didik.

Hasil dari penelitian penulis mengsimpulkan bahwa SMK Negeri 1 Purwokerto belum mempunyai fasilitas untuk pengkasan laporan pencapaian peserta didik secara online. Untuk mengembangkan sistem tersebut, maka penulis mencoba untuk mengembangkan aplikasi rapor berbasis web, yang mana pada aplikasi ini kita bisa mendapatkan informasi mengenai nilai raport siswa yang bersangkutan melalui internet dengan membuka halaman web

yang berisi informasi perkembangan pendidikan siswa dengan fasilitas username dan password. Adapun masalah untuk pengembangan sistem yang berjalan ini, yaitu :

1) Peserta didik tidak mempunyai rekapan data nilainya sendiri bila sewaktuwaktu dibutuhkan untuk kepentingan remedial (perbaikan nilai).

2) Belum tersedianya fasilitas penilaian secara online yang dapat diakses, dibuat dan dirubah oleh guru-guru, sehingga penilaian siswa belum dapat direpserentasikan secara cepat dan akurat.

3) Belum tersedianya fasilitas administrator secara online dimana administrator dapat mengatur database penilaian melalui website kapan saja.

\section{Kelayakan sistem}

\section{a. Kelayakan Teknologi}

Kelayakan teknologi, menyangkut apakah secara operasional sistem yang baru dapat dilaksanakan dengan sumber daya yang tersedia. Sistem ini tidak memerlukan operator yang memiliki keahlian khusus untuk bisa mengoprasikannya. Dilihat dari kemampuan dalam menghasilkan dan menyajikan informasi yang baik serta mudah dipahami, baik dari segi tampilan maupun informasinya. sistem informasi harus benar-benar dibutuhkan oleh pengguna sistem. 


\section{b. Kelayakan Manfaat}

Sebelum sistem informasi dikembangkan maka perlu dihitung komponenkomponen yang perlu disiapkan. Teknik untuk melihat hal ini disebut dengan analisis biaya atau keuntungan. Untuk melakukan analisis biaya atau efektifitas diperlukan dua komponen yaitu komponen biaya dan komponen efektifitas.

\section{c. Kelayakan Ekonomi}

Secara ekonomi sistem ini tidak akan menimbulkan kerugian karena biaya dasar tidak lebih dari manfaat yang diperoleh. Berikut gambaran analisis perincian biaya.

\section{d. Kelayakan Hukum}

Sistem ini layak secara hukum karena dalam pembuatan sistem tidak ada yang melanggar aturan-aturan yang ditetapkan hukum yang diadakan untuk pengadaan aplikasi. Software yang digunakan open source dan hardware diperoleh dengan cara membeli.

\section{e. Kelayakan Waktu}

Tabel 1 Kelayakan waktu

\begin{tabular}{|c|c|c|c|c|c|}
\hline \multirow{2}{*}{ No } & & \multicolumn{3}{|c|}{ Bulan } \\
\cline { 3 - 5 } & Kegiatan & Februari & Maret & April & Mei \\
& Analisis & & & \\
& sistem dan \\
pengumpulan & & & \\
\hline 1 & data & & & \\
\hline 2 & Pembuatan & & & \\
\hline 3 & sistem & & & \\
\hline
\end{tabular}




\section{Desain Sistem}

proses saja. Proses tersebut mewakili proses dari sistem. Dalam menggambar diagram konteks, pertama kali adalah menentukankesatuan luar yang terlibat dalam sistem. Diagram konteks menggambarkan hubungan input dan output antara sistem dengan kesatuan luar.

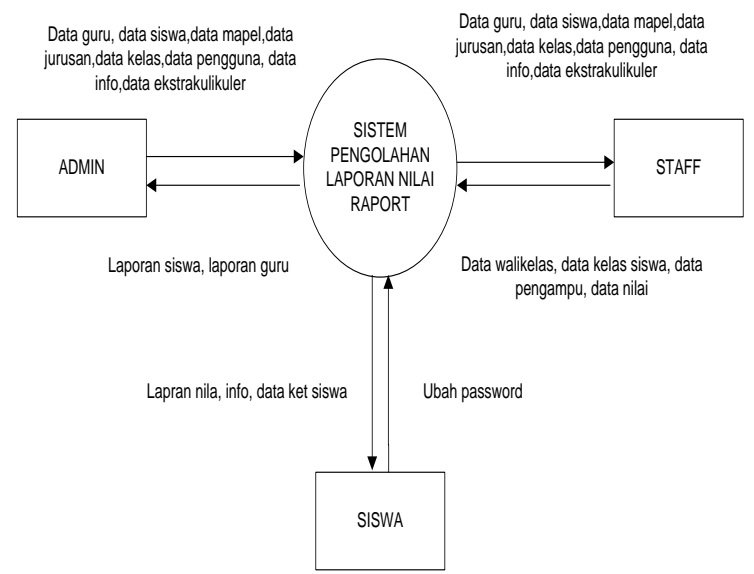

Gambar 2. Diagram Konteks

\section{Pengujian}

Pengujian dilakukan untuk menjamin kualitas dan juga mengetahui kelemahan dari perangkat lunak. Tujuan dari pengujian ini adalah untuk menjamin bahwa perangkay lunak yang dibangun memiliki kualitas analisis, perancangan, dan pengkodean dari perangkat lunak itu sendiri. Pengunjian perangkat lunak ini menggunakan metode pengujian black box. Di mana pengujian black box berfous pada persyaratan fungsional perangkat lunak yang dibuat. Pengujian black box dilakukan untuk antarmuka program, pengujian ini untuk memperlihatkan bahwa fungsi-fungsi bekerja deengan baik, dalam arti masukan yang diterima dengan benar dan keluaran yang dihasilkan benar-benar tepat, integrasi dari eksternal data berjalan dengan baik. 


\section{Implementasi sistem}

Implementasi termasuk pada persiapan implementasi, implementasi perangkat lunak pada lingkungan produksi (lingkungan pada user) dan menjalankan resolusi dari permasalahan yang teridentifikasi dari fase integrasi dan pengujian. Adapun tahapan yang termasuk dalam tahapan implementasi yaitu pengkodean (coding), pengujian (testing), dan konversi.

a) Implementasi Database

Rancangan database yang telah dibuat selanjutnya diimplementasikan menggunakan phpmyadmin. Sistem Pengolhana Laporan Nilai SMK N 1 Purwokerto menggunakan DBMS (Database Management System) MySQL untuk mengolah databasenya. Didalam aplikasi tersebut dibuat sebuah database yang bernama "e-raport" yang nantinya akan menampung seluruh data yang digunakan dan diperlukan dalam Sistem Informasi Pencapaian Kompetensi Pesrta didik SMK N 1 Purwokerto.Tabel nilai mapel umum

Berfungsi untuk mengolah dan menyimpan data nilai mapel umum.

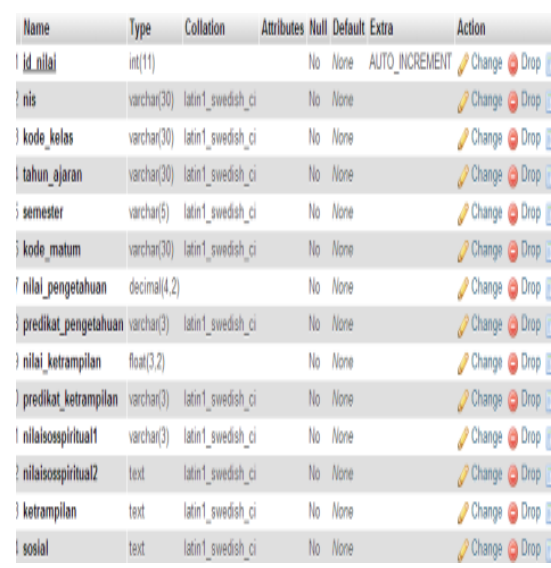

Gambar 3 Struktur Tabel Nilai Mapel Umum 
b) Implementasi Software

Seluruh desain yang dibangun dan dikodekan dengan menggunakan software Dreamweaver. Pembuatan dialog layar atau desain secara terinci merupakan kelanjutan dari desain database yang telah dirancang. Dengan adanya desain secara terinci mengenai antarmuka atau tampilan dalam bentuk website. Sebelum desain antar muka muncul maka kita harus login terlebih dahulu, dapat dilihat pada gambar berikut :Halaman Peginputan Nilai Mapel.

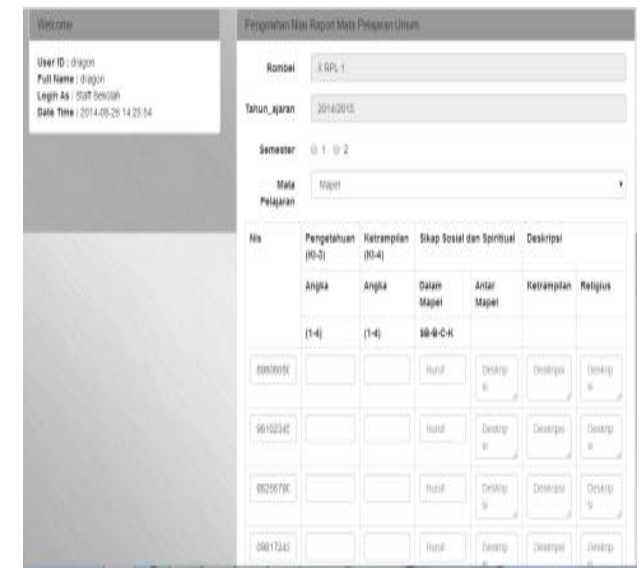

Gambar 4 Antarmuka Penginputan Nilai Mapel

Antarmuka ini digunakan untuk tambah sismpan hapus dan penyimpanan data nilai mapel

1) Halaman sistem laporan pencapaian kompetensi peserta didik

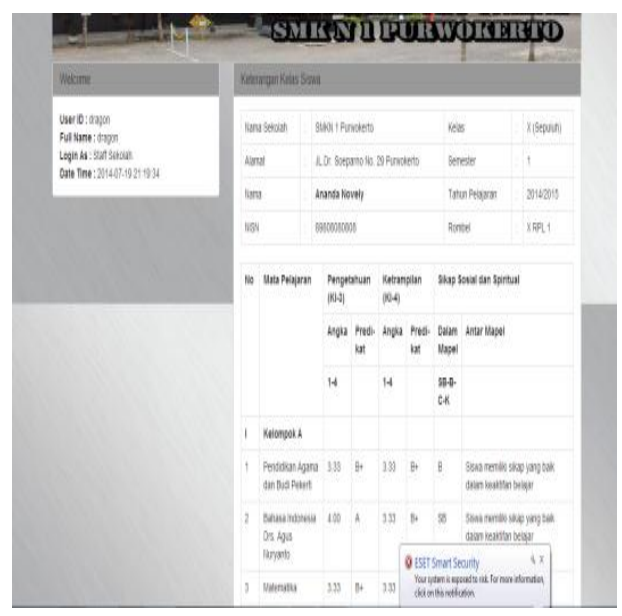

Gambar 5 Antarmuka laporan Pencapaian Kompetensi 
Antarmuka ini digunakan untuk pengpublikasian laporan nilai kepada siswa yand data tersebut akan disimpan di data verifikasi.

\section{Perawatan Sistem}

Setelah sistem informasi laporan pencapian kompetensi peserta didik di SMK N 1 Purwokerto dijalankan, sistem harus selalu melalui tahapan operasional dan pemeliharaan. Hal ini bertujuan untuk memantau kinerja aplikasi (program). Apakah terdapat kesalahan-kesalahan yang tidak diketahui pada saat pengujian.

Tahapan yang termasuk kedalam operasi dan perawatan adalah sebagai berikut :

a. Pelatian Personil

Tujuan dari pelatihan personil adalah untuk memberikan pelatihan kepada pengguna (brainware) tentang cara mengoperasikan program aplikasi yang telah dibuat. Pengguna sistem yaitu admin dan user harus mengetahui sedikitnya masalah yang terjadi pada saat menjalankan program, pengoperasian komputer, pemeliharaan dan perawatan aplikasi.

b. Pemeliharaan sistem

1) Back up Database

Metode ini perlu dilakukan agar untuk menyimpan cadangan database. Apabila ada kerusakan database, maka backup database bisa digunakan untuk mengembalikan kondisi database kedalam kondisi yang lebih baik.

2) Restore

Metode ini digunakan untuk mengembalikan database yang sudah di back up, apabila mengalami kerusakan. 


\section{KESIMPULAN DAN SARAN}

Dari penelitian yang telah dilakukan diperoleh kesimpulan adalah telah dibagung sistem informasi lapoarn pencapaian kompetensi di SMK Negeri Purwokerto sebagai sarana memberikan nilai peserta didik.

Guna perkembangan yang lebih baik untuk kedepan, maka penulis berusaha untuk mengajukan beberapa pemikiran dan saran, antara lain :

1. Pengembangan tampilan website yang lebih baik dan lebih interaktif, sehingga dapat menarik perhatian

2. Untuk menggunakan dan membuka sistem ini Sistem ini hanya terbatas pada urusan nilai saja disarankan pengembangan sistem yang lebih komplek seperti pendaftaran siswa baru, perupustakaan online serta fasilitas $e$-learning.

\section{DAFTAR PUSTAKA}

Jogiyanto HM. 2005, Analisis dan Desain Sistem Informasi: Pendekatan Tersetruktur Teori dan Praktek Aplikasi Bisnis. Yogyakarta: Andi

Fathansyah. 2012.Basis Data Edisi Revisi. Bandung: Informatika

Rosa., Shalahuddin. 2011. Rekayasa Perangkat Lunak Terstruktur dan Berorientasi Objek. Bandung: Informatika

Hidayat, Rahmat. 2010. Cara Praktis Membangun Website gratis. Jakarta: PT Elek Media Komputindo 